\title{
Reaeration and oxygen dissipation into a circular hydraulic channel: experimental and dimensionless approach
}

\author{
Reaeração e dissipação de oxigênio em um canal hidráulico circular: \\ uma abordagem experimental e adimensional
}

\author{
Felipe Keiji Feital Harano ${ }^{1}$, Murilo de Souza Ferreira ${ }^{2}$, Marcos Vinícius Mateus ${ }^{1}$, Deusmaque Carneiro Ferreira ${ }^{1}$ \\ and Julio Cesar de Souza Inácio Gonçalves ${ }^{1}$ \\ ${ }^{1}$ Departamento de Engenharia Ambiental, Universidade Federal do Triângulo Mineiro, Uberaba, MG, Brasil \\ ${ }^{2}$ Escola de Engenharia de São Carlos, Universidade de São Paulo, São Carlos, SP, Brasil \\ E-mails: felipe_harano@hotmail.com (FKFH), muriloferreira@usp.br (MSF), mar.vi.m@outlook.com (MVM), \\ deusmaque.ferreira@uftm.edu.br(DCF),julio.goncalves@uftm.edu.br (JCSIG)
}

Received: July 04, 2017 - Revised: December 05, 2017 - Accepted: March 01, 2018

\begin{abstract}
Dissolved oxygen (DO) is a key parameter in water quality. The DO concentration in a water body can be changed by interfacial phenomena such as reaeration and oxygen dissipation, which can be represented by the coefficients $\mathrm{K}_{2}$ and $\mathrm{K}_{\mathrm{D}}$, respectively. Few studies have jointly correlated $\mathrm{K}_{2}$ and $\mathrm{K}_{\mathrm{D}}$ with physical and hydraulic parameters of the channel. The present work investigated the behavior of these coefficients over a range of hydraulic conditions, and developed semi-empirical equations capable of relating both coefficients. Reaeration and DO dissipation tests were conducted in a circular hydraulic channel with flow velocity ranging from 0.20 to $0.79 \mathrm{~m} . \mathrm{s}^{-1}$ and depth ranging from 0.09 to $0.15 \mathrm{~m}$. Estimates of $\mathrm{K}_{2}$ and $\mathrm{K}_{\mathrm{D}}$ were performed using the non-linear regression method. Semi-empirical equations were obtained based on classical dimensional analysis and multiple regression analysis. The comparison between measured and estimated coefficients yielded $R^{2}$ for reaeration and dissipation of 0.940 and 0.844 , respectively. $K_{D}$ was higher than $K_{2}$ for all turbulence levels applied at the hydraulic channel. An estimate obtained by the relation between the semi-empirical equations indicates that the transfer of oxygen in the water-air direction (dissipation) is approximately twice as fast as the transfer in the air-water direction (reaeration).
\end{abstract}

Keywords: Supersaturation; DO dissipation; Reoxygenation; Prediction model; $\mathrm{K}_{2}$.

\section{RESUMO}

O oxigênio dissolvido (OD) é um dos principais parâmetros de qualidade da água. O equilíbrio da concentração de OD em um corpo d'água pode ser alterado por fenômenos interfaciais como a reaeração e a dissipação de oxigênio, os quais podem ser representados pelos coeficientes $\mathrm{K}_{2}$ e $\mathrm{K}_{\mathrm{D}}$, respectivamente. Poucos estudos correlacionaram conjuntamente $\mathrm{K}_{2}$ e $\mathrm{K}_{\mathrm{D}}$ a parâmetros físicos e hidráulicos do escoamento. Este trabalho investigou o comportamento desses coeficientes em diferentes condições hidráulicas do escoamento, bem como desenvolveu equações semi-empíricas capazes de relacionar ambos coeficientes. Os testes de reaeração e de dissipação foram conduzidos em um canal hidráulico circular com velocidade do escoamento variando de 0,20 a 0,79 m.s. $\mathrm{s}^{-1}$ a profundidade de 0,09 a $0,15 \mathrm{~m}$. As estimativas de $\mathrm{K}_{2}$ e $\mathrm{K}_{\mathrm{D}}$ foram realizadas com o uso do método da regressão não linear. As equações semi-empíricas foram obtidas com base na análise dimensional clássica e na análise de regressão exponencial multiparamétrica. A comparação entre os coeficientes medidos e estimados produziu coeficientes de determinação $\left(R^{2}\right)$ para a dissipação e reaeração de 0,940 e 0,844 , respectivamente. $K_{\mathrm{D}}$ foi maior do que $\mathrm{K}_{2}$ para todos os níveis de turbulência utilizados no canal hidráulico. Uma estimativa obtida pela relação entre as equações semi-empíricas indica que a transferência de oxigênio no sentido água-ar (dissipação) é aproximadamente duas vezes mais rápida do que a transferência no sentido ar-água (reaeração).

Palavras-chave: Supersaturação; Dissipação de OD; Reoxigenação; Modelo de previsão; $\mathrm{K}_{2}$. 


\section{INTRODUCTION}

In natural water bodies, the concentration of total dissolved gases (TDG) influence directly the life of aquatic biota. Among these gases, dissolved oxygen (DO) is considered an important parameter for the life of aquatic species, being often used as an indicator of the health of water bodies (WILLIAMS; BOORMAN, 2012; MARTIN et al., 2013). The DO concentration can be changed in the aquatic environment due to reaeration and dissipation phenomena. These phenomena correspond to interfacial mechanisms of oxygen transfer, and can be represented by the coefficients $\mathrm{K}_{2}$ and $\mathrm{K}_{\mathrm{D}}$, respectively. When a water body is subsaturated with DO, the transfer occurs preferentially towards air-water direction (reaeration). Whereas supersaturated with DO the oxygen transfer occurs predominantly towards water-air direction (dissipation) (JHA; OJHA; BHATIA, 2004).

Accurate estimation of the reaeration coefficient $\left(\mathrm{K}_{2}\right)$ is important for both water quality modeling (COX, 2003; CHEN et al., 2009; TSUZUKI et al., 2010) and aquatic metabolism assessment (RILEY; DODDS, 2013; DEMARS; THOMPSON; MANSON, 2015).

On the other hand, the dissipation coefficient $\left(\mathrm{K}_{\mathrm{D}}\right)$ is a fundamental parameter for modeling the DO and TDG dissipation phenomena downstream of hydroelectric dams. In these places, the shedding of water can produce supersaturation of the natural water body and induce a potentially fatal fish disease known as gas bubble disease (WEITKAMP et al., 2003; QU et al., 2011a, b; HUANG et al., 2016; CAO et al., 2016; POLITANO; CASTRO; HADJERIOUA, 2017).

Several researchers (MELCHING; FLORES, 1999; JHA; OJHA; BHATIA, 2001, 2004; KALBURGI et al., 2015) have sought to understand the reaeration phenomenon and its relations with the hydraulics and physical parameters of the flow, and have developed several semi-empirical equations for estimation of $\mathrm{K}_{2}$. While other researchers (QU et al., 2011a, b; FENG et al., 2014; SHEN et al., 2014; HUANG et al., 2016) dedicated exclusively to the study of DO and TDG dissipation phenomena in water bodies located downstream of dams.

Li et al. (2013) held the main study so far that investigated the relation between the reaeration and DO dissipation phenomena, under controlled conditions. They showed, through an experimental study in laboratory, that $\mathrm{K}_{2}$ and $\mathrm{K}_{\mathrm{D}}$ are influenced by the flow turbulence. However, a mathematical model that depicts the relation between these coefficients was not developed. In addition, the authors suggested studies in channels and other structures that generate turbulence to investigate the effect of water depth in the process of dissipation.

Hence, despite the breakthrough in understanding the factors that influence the reaeration and DO dissipation phenomena, the development of studies to investigate the correlation between these coefficients under controlled hydraulic conditions still need to be carried out.

The aim of this study was to investigate the similarity between the reaeration and DO dissipation phenomena on tests performed in a circular hydraulic channel and to develop a semi-empirical equation based on dimensional analysis and experimental data.

\section{MATERIAL AND METHODS}

\section{Reaeration and DO dissipation}

Reaeration and DO dissipation tests were conducted in a circular hydraulic channel made of glass fibre-reinforced polymer (GFRP) with $0.62 \mathrm{~m}$ of external diameter, $0.32 \mathrm{~m}$ of internal diameter, and $0.20 \mathrm{~m}$ of depth.

The hydraulic conditions were caused by changing water depth and flow velocity. The water was recirculated through a $0.18 \mathrm{~kW}$ pump system and two pairs of suction and delivery points, distributed along the channel longitudinal profile (Figure 1).

Jets tangent the bottom of the channel provided a transfer of momentum to the liquid body. A valve installed in the delivery pipe set the different flow velocities.

The flow velocity was measured using a small mechanical current meter (accuracy of 1\%), at 6 different positions (Figure 1) and at a height equivalent to $50 \%$ of the water depth. The mean velocity was computed as being the arithmetic average of the six measured values. To measure the depth, a Vernier caliper (accuracy of $0.02 \mathrm{~mm}$ ) was used. The dissolved oxygen concentration

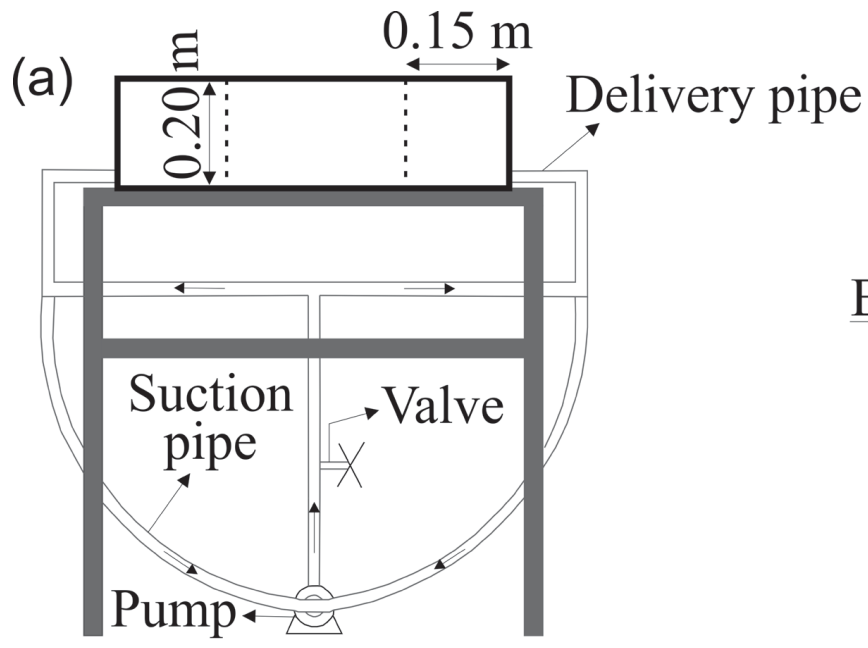

(b)

Velocity measurements

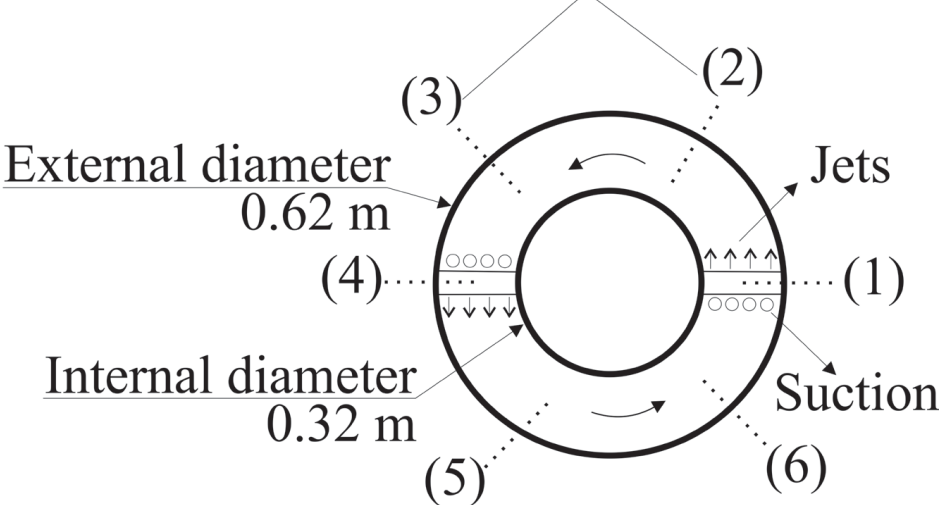

Figure 1. Circular hydraulic channel used in reaeration and DO dissipation tests: (a) longitudinal profile and (b) top view. 
(or saturation) and water temperature were measured with a digital oximeter (accuracy of $0.1 \mathrm{mg} . \mathrm{L}^{-1}$ ) and a thermocouple (accuracy of $0.2{ }^{\circ} \mathrm{C}$ ), respectively. For stabilizing the temperature during the tests, a coil-type heat exchanger was set along the inner wall of the channel.

Reaeration and DO dissipation tests were held under twelve different hydraulic conditions. A pair of mean velocity $(U)$ and water depth $(\mathrm{H})$ represents each hydraulic condition. In this study, the mean velocity of the flow varied from 0.20 to $0.79 \mathrm{~m} . \mathrm{s}^{-1}$ and the depth from 0.09 to $0.15 \mathrm{~m}$.

Before starting the reaeration, the DO was removed from the water using sodium sulfite according to the methodology presented by Maradei et al. (2015) and Adachi (2015).

\section{Supersaturation}

Before the dissipation tests, the water was supersaturated with DO. To this end, the experimental apparatus shown in Figure 2 was used. It was designed based on the work of Qu et al. (2011b), who concluded that the supersaturation of water is carried out more efficiently when aerated with high-speed jets.

In the work of Qu et al. (2011b), the aeration was held using a compressor. In the present work the aeration was conducted by small orifices (diameter of $1 \mathrm{~mm}$ ) in the pump suction pipe, in which the atmospheric air enter apparatus. The aerated water ran from a $3 \mathrm{~m}$ long discharge pipe to a storage tank $(40 \mathrm{~L})$. At the end of the delivery pipe, a nozzle (internal diameter of $3 \mathrm{~mm}$ ) was installed to increase the flow velocity (approximately $50 \mathrm{~m} \cdot \mathrm{s}^{-1}$ ). The high turbulence in the storage tank, associated with the airing in the delivery pipe, yielded a supersaturation with DO of $118 \%$ in just 30 minutes.

\section{Experimental analysis}

The DO reaeration and dissipation phenomena were modeled using a first-order kinetics (Equation 1), as suggested by Li et al. (2013).

$\mathrm{DO} \%_{(\mathrm{t})}=100 \%+\left(\mathrm{DO} \%_{(0)}-100 \%\right) \mathrm{e}^{-\mathrm{K} . \mathrm{t}}$

$\mathrm{DO} \%_{(\mathrm{t})}$ is the percentage of saturation at a given moment and $\mathrm{DO}{ }_{(0)}$ is the initial percentage of saturation. $\mathrm{K}$ is the kinetic coefficient, which can hold the subscripts " 2 " and " $D$ ", to represent the reaeration $\left(\mathrm{K}_{2}\right)$ and DO dissipation $\left(\mathrm{K}_{\mathrm{D}}\right)$ phenomena, respectively, and $\mathrm{t}$ is time.

The tests produce DO $\%$ curves as a function of time. The fitting of the model (Equation 1) to experimental data and the estimation of $\mathrm{K}_{2}$ and $\mathrm{K}_{\mathrm{D}}$ were performed with the use of the technique of nonlinear regression analysis. The values of $\mathrm{K}_{2}$ and $\mathrm{K}_{\mathrm{D}}$ have been corrected to a temperature of $20^{\circ} \mathrm{C}$ using the Arrhenius equation (Equation 2).

$\mathrm{K}\left(20^{\circ} \mathrm{C}\right)=\frac{\mathrm{K}(\mathrm{T})}{\theta^{(\mathrm{T}-20)}}$

where $\theta$ is the temperature correction coefficient whose value adopted for reaeration was 1.0241, as suggested by Elmore and West (1961). For DO dissipation, the adopted value of $\theta$ was 1.060 (SHEN et al., 2014).

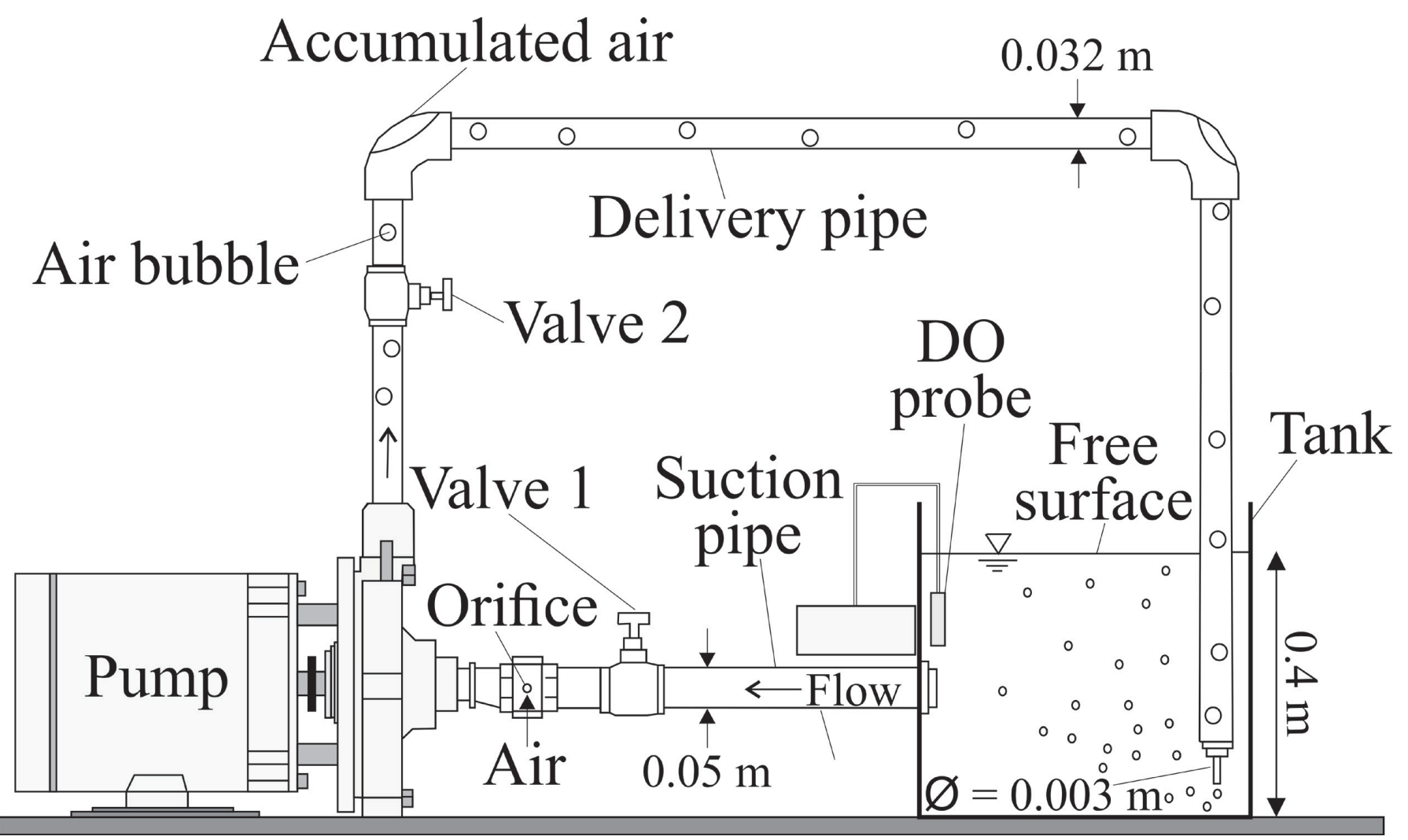

Figure 2. Outline of the experimental apparatus for DO supersaturation. 


\section{Dimensional analysis}

Since the beginning of the twentieth century, several works were carried out with the objective of developing theoretical, semi-empirical, and empirical equations to estimate $\mathrm{K}_{2}$ correctly (LEWIS; WHITMAN, 1924; HIGBIE, 1935; DANCKWERTS, 1951; O'CONNOR; DOBBINS, 1958; CHURCHILL; ELMORE; BUCKINGHAM, 1962; OWENS; EDWARDS; GIBBS, 1964; LANGBEIN; DURUM, 1967; BENNETT; RATHBUN, 1972; JHA; OJHA; BHATIA, 2001). In recent years, in an attempt to improve the estimation of $\mathrm{K}_{2}$, researchers have developed equations based on dimensional analysis and experimental results (GUALTIERI; GUALTIERI; DORIA, 2002; GUALTIERI; DORIA, 2012; MARADEI et al., 2015; QUEIROZ; MATOS; VON SPERLING, 2015). These studies have shown that traditional hydraulic parameters (Reynolds, Froude, $\mathrm{U}$ and $\mathrm{H}$ ) exert high influence on the reaeration phenomenon.

Concerning to DO dissipation, Qu et al. (2011a, b) and Li et al. (2015) showed that flow velocity, water depth, aspect ratio of the channel, shear Reynolds number, and turbulence are important factors to the dissipation phenomenon control.

Hence, this study developed equations based on dimensional analysis and experimental results obtained here to estimate $\mathrm{K}_{2}$ and $\mathrm{K}_{\mathrm{D}}$. The basic parameters chosen for the modeling of these coefficients were gravity, $g\left[\mathrm{~L}^{2} \cdot \mathrm{T}^{-1}\right]$, kinematic viscosity of

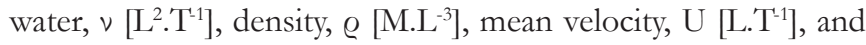
water depth, $\mathrm{H}[\mathrm{L}]$.

The application of dimensional analysis resulted in the following equation:

$$
\mathrm{F}(\mathrm{K}, \mathrm{g}, \mathrm{v}, \rho, \mathrm{U}, \mathrm{H})=0
$$

Applying the theorem of Vaschy-Buckingham and choosing the parameters $\mathrm{H}, \mathrm{U}$ and $\varrho$ as repeated variables, the Equation 3 becomes:

$$
\mathrm{F}\left(\frac{\mathrm{K} \cdot \mathrm{H}}{\mathrm{U}}, \mathrm{Re}, \mathrm{Fr}\right)=0
$$

where Re is the Reynolds number $\left(\mathrm{U} . \mathrm{H} . \mathrm{v}^{-1}\right)$ and Fr is the Froude number $\left(\mathrm{U}^{-0} \mathrm{~g}^{-0.5} \cdot \mathrm{H}^{-0.5}\right)$.
Considering the dimensionless ratio defined by Equation 4, in which Re and Fr are independent variables and K.H.U ${ }^{-1}$ is the dependent variable, it becomes possible to adopt a power-law model to describe the relationship of dependency between them (Equation 5):

$$
\frac{\mathrm{K} \cdot \mathrm{H}}{\mathrm{U}}=\mathrm{aRe}^{\mathrm{b}} \mathrm{Fr}^{\mathrm{c}}
$$

where, "a", "b" and "c" are dimensionless and were estimated from the experimental data and multiple regression analysis.

\section{RESULTS AND DISCUSSION}

\section{Analysis of the experimental data}

Table 1 shows the hydraulic conditions under which the reaeration and DO dissipation tests were carried out and the main results found. The values of the coefficient $\mathrm{K}_{2}$ ranged from $1.25 \times 10^{-4}$ to $9.14 \times 10^{-4} \mathrm{~s}^{-1}$ and $K_{D}$ coefficients ranged from $1.56 \times 10^{-4}$ to $1.73 \times 10^{-3} \mathrm{~s}^{-1}$. About the hydraulic parameters, Reynolds number (Re) ranged from $44.6 \times 10^{3}$ to $197.3 \times 10^{3}$ and Froude number (Fr) from 0.17 to 0.65 .

Figure 3 presents the curves of $\mathrm{DO} \%$ as a function of time for tests 1, 4, 8, and 11; as well as a supersaturation curve obtained during the tests carried out in the experimental apparatus shown in Figure 2. There is a good fit between the model (Equation 1) and the experimental data. All tests showed $\mathrm{R}^{2}$ (coefficient of determination) higher than 0.98 , indicating that physical phenomena, such as the sinks caused by low-pressure areas in the pipe that feeds the channel, are insignificant to the apparatus built in this study. Gonçalves et al. (2013) show the effect of physical sinks on water agitation systems.

As expected, the flow turbulence intensity exerted high influence on the reaeration and dissipation phenomena (i.e. $\mathrm{K}_{\mathrm{D}}$ and $\mathrm{K}_{2}$ increased with the turbulence). In this study, the turbulence intensity increased in response to increasing flow velocity and decreasing water depth.

An important observation is that the experimental ratio between $K_{D}$ and $K_{2}$ was not constant in relation to turbulence

\begin{tabular}{|c|c|c|c|c|c|c|c|}
\hline Test & $\mathrm{H}(\mathrm{m})$ & $\mathrm{U}\left(\mathrm{m} \cdot \mathrm{s}^{-1}\right)$ & ${ }^{\mathrm{a}} \operatorname{Re}\left(\mathrm{x} 10^{3}\right)$ & ${ }^{\mathrm{b}} \mathrm{Fr}$ & ${ }^{c} K_{D}\left(s^{-1}\right)$ & ${ }^{\mathrm{c}} \mathbf{K}_{2}\left(\mathrm{~s}^{-1}\right)$ & ${ }^{\mathrm{d}} \mathbf{K}_{\mathrm{D}} / \mathbf{K}_{2}$ \\
\hline 1 & 0.09 & 0.22 & 44.6 & 0.24 & $3.01 \times 10^{-4}$ & $1.69 \times 10^{-4}$ & 1.8 \\
\hline 2 & 0.09 & 0.37 & 75.0 & 0.40 & $5.94 \times 10^{-4}$ & $3.65 \times 10^{-4}$ & 1.6 \\
\hline 3 & 0.09 & 0.49 & 98.2 & 0.52 & $1.14 \times 10^{-3}$ & $4.18 \times 10^{-4}$ & 2.7 \\
\hline 4 & 0.09 & 0.58 & 117.7 & 0.62 & $1.73 \times 10^{-3}$ & $9.14 \times 10^{-4}$ & 1.9 \\
\hline 5 & 0.12 & 0.23 & 53.3 & 0.22 & $1.69 \times 10^{-4}$ & $1.42 \times 10^{-4}$ & 1.1 \\
\hline 6 & 0.12 & 0.38 & 87.5 & 0.35 & $3.35 \times 10^{-4}$ & $2.05 \times 10^{-4}$ & 1.5 \\
\hline 8 & 0.12 & 0.56 & 128.3 & 0.51 & $8.06 \times 10^{-4}$ & $4.63 \times 10^{-4}$ & 1.7 \\
\hline 9 & 0.15 & 0.21 & 51.8 & 0.17 & $1.56 \times 10^{-4}$ & $1.25 \times 10^{-4}$ & 1.2 \\
\hline 10 & 0.15 & 0.34 & 84.0 & 0.28 & $2.26 \times 10^{-4}$ & $1.79 \times 10^{-4}$ & 1.3 \\
\hline 11 & 0.15 & 0.64 & 160.2 & 0.53 & $6.28 \times 10^{-4}$ & $2.61 \times 10^{-4}$ & 2.4 \\
\hline 12 & 0.15 & 0.79 & 197.3 & 0.65 & $6.60 \times 10^{-4}$ & $2.98 \times 10^{-4}$ & 2.2 \\
\hline
\end{tabular}
(ranged from 1.1 to 2.7). Despite this variation, the results showed

Table 1. Hydraulic conditions under which the tests were performed.

${ }^{(a)}$ Reynolds number (dimensionless); (b) Froude number (dimensionless); ${ }^{(c)}$ Adjusted coefficients for the standard temperature of $20{ }^{\circ} \mathrm{C}$; ${ }^{(d)} \mathrm{K}_{\mathrm{D}} / \mathrm{K}_{2}$ ratio. 
that the DO dissipation rate is higher than the reaeration rate. Li et al. (2013) found different results, since in their experiments the dissipation rate was not always higher than the reaeration rate. Therefore, they concluded that the reaeration coefficient is not a sustainable proxy of the dissipation coefficient. The difference between the results can be explained by the distinct equipment used to generate turbulence. In this study it was used a circular hydraulic channel, while Li et al. (2013) used a cylindrical water container with a $14 \mathrm{~L}$ capacity equipped with an electric stirrer.

\section{Dimensionless ratios from the experimental data}

Table 2 shows the values of "a", "b", and "c" found using multiple regression analysis. These values have yielded coefficients of determination for the dissipation and reaeration phenomena of 0.945 and 0.844 , respectively.

Considering that the values of " $b$ " and "c" found for dissipation were akin to those found for reaeration, it was decided to use the same values of " $\mathrm{b}$ " and " $\mathrm{c}$ " for both phenomena $(b=-1.16$ and $c=1.70)$ and to adjust again the values for "a", which became equal to 430 for dissipation and 210 for reaeration. This strategy practically did not change the quality of the fitting between obtained equations and experimental data, since the coefficients of determination for the phenomena were minimally changed ( 0.940 for dissipation and 0.844 for reaeration).

The replacement of the constants in Equation 5 yielded the following equations for the dissipation and reaeration phenomena, respectively:

$$
\begin{aligned}
& \mathrm{K}_{\mathrm{D}}=430 \frac{\mathrm{Fr}^{1.70} \cdot \mathrm{U}}{\mathrm{Re}^{1.16} \cdot \mathrm{H}} \\
& \mathrm{K}_{2}=210 \frac{\mathrm{Fr}^{1.70} \cdot \mathrm{U}}{\mathrm{Re}^{1.16} \cdot \mathrm{H}}
\end{aligned}
$$

Figure 4 shows the comparison of the coefficients $K_{2}$ and $K_{D}$ measured experimentally and estimated by Equations 6 and 7 . The form of Equation 6 confirms the speculation held by Li et al. (2013) that reducing the water depth is a method to reduce the length of rivers affected by supersaturation, because the smaller is $H$, the higher $K_{D}$.

It can be observed also that the relation between the Equations 6 and $7\left(\mathrm{~K}_{\mathrm{D}} / \mathrm{K}_{2}\right)$ yielded a value of 2.05 (dissipation is possibly twice as fast as reaeration). This result shows that the relationship between the DO dissipation and reaeration phenomena can be approximated by a constant that is independent of turbulence.

The fact that $K_{D}$ is higher than $K_{2}$, whereas the similar conditions of temperature and turbulence, can be explained by entropic differences and variable quantities of stored energy (mainly the vibrational energy of oxygen molecules) in the reaeration and dissipation phenomena (Figure 5).

Table 2. Dimensionless constants obtained from the adjustment of semi-empirical equations.

\begin{tabular}{cccc}
\hline Coefficients & $\mathbf{a}$ & $\mathbf{b}$ & $\mathbf{c}$ \\
\hline $\mathbf{K}_{\mathbf{D}}$ & 469 & -1.16 & 1.92 \\
$\mathbf{K}_{2}$ & 221 & -1.16 & 1.69 \\
\hline
\end{tabular}
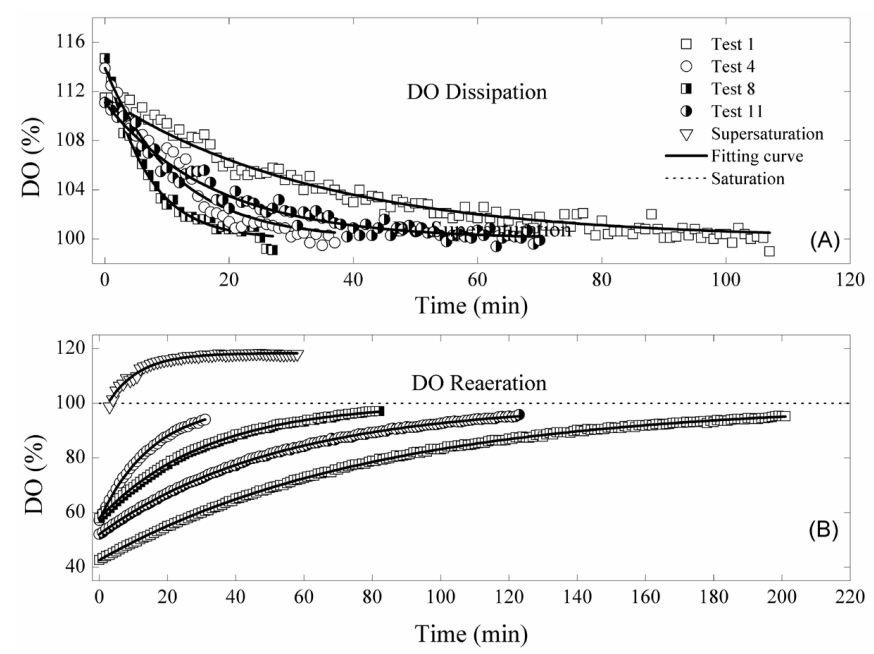

Figure 3. Main experimental results adjusted to the models. (A) DO dissipation Phenomena; (B) reaeration phenomena and supersaturation of DO.
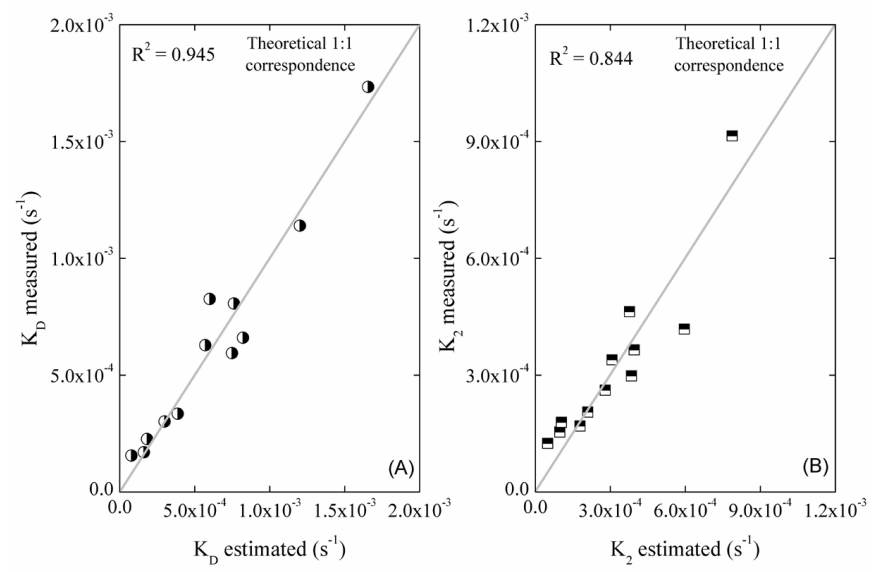

Figure 4. (A) Comparison between measured and estimated $K_{D}$ and (B) comparison between measured and estimated $\mathrm{K}_{2}$.

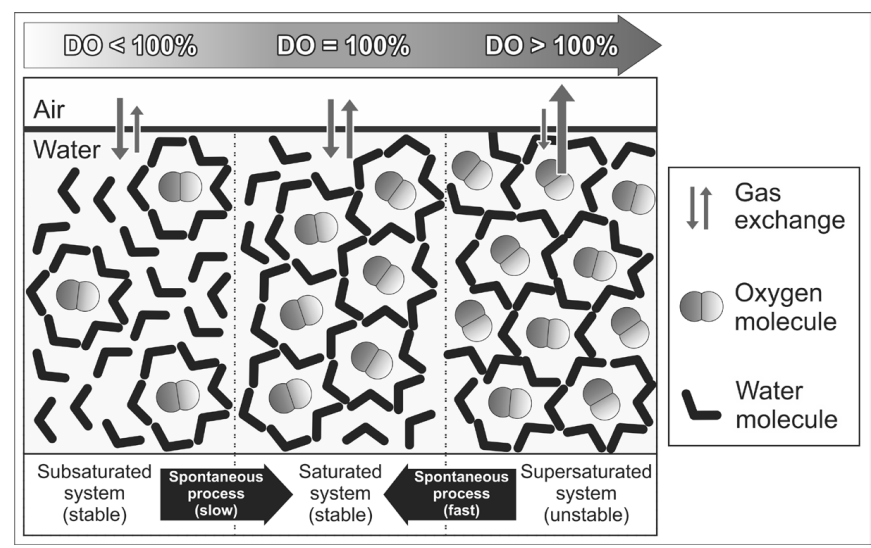

Figure 5. Schema of the water and oxygen molecules arrangement in the circular hydraulic channel under subsaturation $(\mathrm{DO}<100 \%)$, saturation $(\mathrm{DO}=100 \%)$ and supersaturation conditions $(\mathrm{DO}>100 \%)$. 
The schema in Figure 5 shows the degree of organization (entropy) of the interaction between oxygen molecules and water molecules under conditions of subsaturation (reaeration), saturation (equilibrium) and supersaturation (dissipation).

The saturation point $(\mathrm{DO}=100 \%)$ represents a stability limit on DO concentration for the water in the channel (Figure 5). A supersaturated system $(\mathrm{DO}>100 \%)$ can exist in special conditions, such as the high turbulence associated with flow aeration that happens downstream the spillways of large dams and at the experimental apparatus used in this study (Figure 2). This supersaturated system is unstable, because of the high vibrational energy of dissolved oxygen molecules and the low entropy (low disorder, high number of oxygen molecules in the volume of water in the channel). In general, once ceased the external force responsible for causing the supersaturation, the system returns spontaneously and quickly to saturation, stability (less vibrational energy in dissolved oxygen molecules) and high entropy (higher disorder, fewer oxygen molecules in volume of water in the channel) state.

On the other hand, the reaeration phenomenon occurs in a subsaturated system ( $\mathrm{DO}<100 \%$ ), which is stable and has higher entropy and lower energy stored in oxygen molecules. In this system, the return to a saturated state is spontaneous, however it occurs more slowly than in the supersaturated system (DO $>100 \%$ ).

\section{CONCLUSIONS}

The paper investigated the similarity between the reaeration and DO dissipation phenomena in a circular hydraulic channel under different hydraulic conditions. In the face of the results, it is possible to conclude that:

1) The experimental apparatus used to produce water supersaturated with oxygen proved efficient. In only 30 minutes, the DO percentage in the water reached $118 \%$. In addition, the apparatus can be easily built and operated, making it a viable alternative for future studies involving of DO supersaturation phenomena;

2) Experimental data showed that the DO dissipation rate is higher than the reaeration rate. This statement was valid for all levels of turbulence used in the circular hydraulic channel;

3) The relationship among the semi-empirical equations yielded a constant equal to 2.05 , which can be used to estimate $\mathrm{K}_{\mathrm{D}}$ from $\mathrm{K}_{2}$;

4) The relation obtained between $K_{D}$ and $K_{2}$ is restricted to the hydraulic conditions tested in this work; Therefore, it is recommended to analyze the dissipation and reaeration phenomena using other apparatus for turbulence generation (such as a tank with oscillating grids and a tank agitated by jets) and also in natural flows.

\section{ACKNOWLEDGEMENTS}

To FAPEMIG by financial support.

\section{REFERENCES}

ADACHI, T. Oxygen transfer and power consumption in an aeration system using mist and circulation flow generated by a rotating cone. Chemical Engineering Science, v. 126, p. 625-632, 2015. http://dx.doi.org/10.1016/j.ces.2015.01.009.

BENNETT, J. P.; RATHBUN, R. E. Reaeration in open channel flow. Washington: U. S. Department of the Interior, 1972. (U.S. Geological Survey Professional Paper, No. 737).

CAO, L.; LIANG, R.; TUO, Y.; LI, Y.; LI, K. Influence of total dissolved gas-supersaturated water on silver carp (Hypophthalmichthys molitrix). Water Science and Engineering, v. 9, n. 4, p. 324-328, 2016. http://dx.doi.org/10.1016/j.wse.2017.01.001.

CHEN, Q.; TAN, K.; ZHU, C.; LI, R. Development and application of a two-dimensional water quality model for the Daqinghe River Mouth of the Dianchi Lake. Journal of Environmental Sciences, v. 21, n. 3, p. 313-318, 2009. http://dx.doi.org/10.1016/S10010742(08)62270-6. PMid:19634442.

CHURCHILL, W. E.; ELMORE, H. L.; BUCKINGHAM, R. A. Prediction of stream reaeration rates. Journal of the Sanitary Engineering Division, v. 88, n. 4, p. 1-46, 1962.

COX, B. A. A review of dissolved oxygen modelling techniques for lowland rivers. The Science of the Total Environment, v. 314-316, n. 3, p. 303-334, 2003. http://dx.doi.org/10.1016/S0048-9697(03)000627. PMid:14499539.

DANCKWERTS, P. V. Significance of liquid-film coefficients in gas absorption. Industrial \& Engineering Chemistry, v. 43, n. 6, p. 1460-1467, 1951. http://dx.doi.org/10.1021/ie50498a055.

DEMARS, B. O. L.; THOMPSON, J.; MANSON, J. R. Stream metabolism and the open diel oxygen method: Principles, practice, and perspectives. Limnology and Oceanography, Methods, v. 13, n. 7, p. 356-374, 2015. http://dx.doi.org/10.1002/lom3.10030.

ELMORE, H. L.; WEST, W. L. Effect of water temperature on stream reaeration. Journal of the Sanitary Engineering Division, v. 87, p. 59-71, 1961.

FENG, J.; LI, R.; MA, Q.; WANG, L. Experimental and field study on dissipation coefficient of supersaturated total dissolved gas. Journal of Central South University, v. 21, n. 5, p. 1995-2003, 2014. http://dx.doi.org/10.1007/s11771-014-2148-4.

GONÇALVES, J. C. S. I.; COSTA, D. J. L.; SILVEIRA, A.; GIORGETTI, M. F. Reoxigenação superficial e sumidouro físico de oxigênio dissolvido em um tanque agitado por jatos. Revista 
Brasileira de Recursos Hídricos, v. 18, n. 3, p. 231-240, 2013. http:/ / dx.doi.org/10.21168/rbrh.v18n3.p231-240.

GUALTIERI, C.; DORIA, G. P. Gas-transfer at unsheared freesurfaces. In: GUALTIERI, C.; MIHAILOVIC, D. T. Fluid mechanics of environmental interfaces. Netherlands: CRC Press/Balkema, 2012. Cap. 6, p. 131-162.

GUALTIERI, C.; GUALTIERI, P.; DORIA, G. P. Dimensional analysis of reaeration rate in streams. Journal of Environmental Engineering, v. 128, n. 1, p. 12-18, 2002. http://dx.doi.org/10.1061/ (ASCE)0733-9372(2002)128:1(12).

HIGBIE, R. The rate of absorption of a pure gas into a still liquid during short periods of exposure. Transctions of the AIChE, v. 31 , p. 365-389, 1935.

HUANG, J.; LI, R.; FENG, J.; XU, W.; WANG, L. Relationship investigation between the dissipation process of supersaturated total dissolved gas and wind effect. Ecological Engineering, v. 95, p. 430-437, 2016. http://dx.doi.org/10.1016/j.ecoleng.2016.06.042.

JHA, R.; OJHA, C. S. P.; BHATIA, K. K. S. Refinement a predictive reaeration equations for a typical Indian river. Hydrological Processes, v. 15, n. 6, p. 1047-1060, 2001. http://dx.doi.org/10.1002/hyp.177.

JHA, R.; OJHA, C. S. P.; BHATIA, K. K. S. A supplementary approach for estimating reaeration rate coefficients. Hydrological Processes, v. 18, n. 1, p. 65-79, 2004. http://dx.doi.org/10.1002/ hyp.1312.

KALBURGI, P. B.; JHA, R.; OJHA, C. S. P.; DESHANNAVAR, U. B. Evaluation of re-aeration equations for river Ghataprabha, Karnataka, India and development of refined equation. Environmental Technology, v. 36, n. 1-4, p. 79-85, 2015. http://dx.doi.org/10.108 0/09593330.2014.937770. PMid:25409586.

LANGBEIN, W. B.; DURUM, W. H. The aeration capacity of streams. Washington: U. S. Department of the Interior, 1967. (U.S. Geological Survey Circular, No. 542).

LEWIS, W. K.; WHITMAN, W. G. Principles of gas absorption. Industrial \& Engineering Chemistry, v. 16, n. 12, p. 1215-1220, 1924. http://dx.doi.org/10.1021/ie50180a002.

LI, R.; GUALTIERI, P.; FENG, J.; GUALTIERI, C. A dimensional analysis of supersaturated total dissolved gas dissipation. In: IAHR WORLD CONGRESS, 36., 2015, The Netherlands. Proceedings... The Hague: AIRH, 2015. p. 1-8.

LI, R.; HODGES, B. R.; FENG, J.; YONG, X. Comparison of supersaturated total dissolved gas dissipation with dissolved oxygen dissipation and reaeration. Journal of Environmental Engineering, v. 139, n. 3, p. 385-390, 2013. http://dx.doi.org/10.1061/(ASCE) EE.1943-7870.0000598.
MARADEI, G.; VELTRI, P.; MOROSINI, A. F.; VERBENI, B. Laboratory study on the open channel flow reaeration: a dimensional approach. Urban Water Journal, v. 12, n. 4, p. 295-304, 2015. http://dx.doi.org/10.1080/1573062X.2014.896930.

MARTIN, N.; MCEACHERN, P.; YU, T.; ZHU, D. Z. Model development for prediction and mitigation of dissolved oxygen sags in the Athabasca River, Canada. The Science of the Total Environment, v. 443, p. 403-412, 2013. http://dx.doi.org/10.1016/j. scitotenv.2012.10.030. PMid:23202384.

MELCHING, C. S.; FLORES, H. E. Reaeration equations derived from U.S. Geological Survey database. Journal of Environmental Engineering, v. 125, n. 5, p. 407-414, 1999. http://dx.doi.org/10.1061/ (ASCE)0733-9372(1999)125:5(407).

O'CONNOR, D. J.; DOBBINS, W. E. Mechanism of reaeration in natural streams. Transactions of the American Society of Civil Engineers, v. 123, n. 1, p. 641-666, 1958.

OWENS, S.; EDWARDS, R. W.; GIBBS, J. W. Some reaeration studies in streams. Air and Water Pollution, v. 8, n. 819, p. 469-486, 1964. PMid:14215805.

POLITANO, M.; CASTRO, A.; HADJERIOUA, B. Modeling total dissolved gas for optimal operation of multi-reservoir systems. Journal of Hydraulic Engineering, v. 143, n. 6, p. 1-12, 2017. http:// dx.doi.org/10.1061/(ASCE)HY.1943-7900.0001287.

QU, L.; LI, R.; LI, J.; LI, K.; DENG, Y. Field observation of total dissolved gas supersaturation of high-dams. Science China. Technological Sciences, v. 54, n. 1, p. 156-162, 2011a. http://dx.doi. org/10.1007/s11431-010-4217-8.

QU, L.; LI, R.; LI, J.; LI, K.; WANG, L. Experimental study on total dissolved gas supersaturation in water. Water Science and Engineering, v. 4, p. 396-404, 2011 b.

QUEIROZ, F. M.; MATOS, A. T.; VON SPERLING, M. Estimativa do coeficiente de reaeração da água em canal raso de fundo deslizante. Engenharia Sanitaria e Ambiental, v. 20, n. 1, p. 79-88, 2015. http://dx.doi.org/10.1590/S1413-41522015020000113819.

RILEY, A. J.; DODDS, W. K. Whole-stream metabolism: strategies for measuring and modeling diel trends of dissolved oxygen. Freshwater Science, v. 32, n. 1, p. 56-59, 2013. http:/ /dx.doi. org/10.1899/12-058.1.

SHEN, X.; LIU, S.; LI, R.; OU, Y. Experimental study on the impact of temperature on the dissipation process of supersaturated total dissolved gas. Journal of Environmental Sciences, v. 26, n. 9, p. 1874-1878, 2014. http://dx.doi.org/10.1016/j.jes.2014.02.002. PMid:25193837. 
TSUZUKI, Y.; FUJII, M.; MOCHIHARA, Y.; MATSUDA, K.; YONEDA, M. Natural purification effects in the river in consideration with domestic wastewater pollutant discharge reduction effects. Journal of Environmental Sciences, v. 22, n. 6, p. 892-897, 2010. http:// dx.doi.org/10.1016/S1001-0742(09)60194-7. PMid:20923102.

WEITKAMP, D. E.; SULLIVAN, R. D.; SWANT, T.; DOSSANTOS, J. Gas bubble disease in resident fish of the Lower Clark Fork River. Transactions of the American Fisheries Society, v. 132, n. 5, p. 865-876, 2003. http://dx.doi.org/10.1577/T02-026.

WILLIAMS, R. J.; BOORMAN, D. B. Modelling in-stream temperature and dissolved oxygen at sub-daily time steps: An application to the River Kennet, UK. The Science of the Total Environment, v. 423, p. 104-110, 2012. http://dx.doi.org/10.1016/j. scitotenv.2012.01.054. PMid:22401790.

\section{Authors contributions}

Felipe Keiji Feital Harano: Initial conception of the research; literature search; data collection; writing and formatting of the paper.

Murilo de Souza Ferreira: Review of previous work; writing and formatting of the paper; and discussion of the results.

Marcos Vinícius Mateus: Review of previous work; formulation of the Dimensionless ratios; and discussion of the results.

Deusmaque Carneiro Ferreira: Review of previous work; formulation of the Dimensionless ratios; and discussion of the results.

Julio Cesar de Souza Inácio Gonçalves: Advisor Professor; initial conception of the research; analysis of results and drafting the paper. 